\author{
ARKADIUSZ ŻUKIEWICZ \\ Uniwersytet Opolski
}

\title{
PODSTAWOWE ZAGADNIENIA POLSKIEJ PEDAGOGIKI SPOŁECZNEJ U PROGU PROCESU DYSCYPLINARYZACJI
}

\begin{abstract}
Aвstract. Żukiewicz Arkadiusz, Podstawowe zagadnienia polskiej pedagogiki społecznej u progu procesu dyscyplinaryzacji [Basic Issues of Polish Social Pedagogy at the Beginning of the Disciplinary Process]. Studia Edukacyjne nr 51, 2018, Poznań 2018, pp. 211-226. Adam Mickiewicz University Press. ISSN 1233-6688. DOI: $10.14746 /$ se.2018.51.12
\end{abstract}

The article presents the basic issues of social pedagogy presented by Helena Radlińska in 1908 during a meeting at the Krakow Circle of Teachers of Higher Schools in Krakow. In her talk, she presented issues of education and social development in a wider historical background. She made reference to international and national experiences. In the conclusion of her speech, she called for the dissemination and socialization of upbringing and social assistance for the poorest social groups.

Key words: Helena Radlińska, social work, social development, historical research

\section{Wstęp}

Rok 2018 stanowi kolejną pełną rocznicę, która czyni okazję pedagogom społecznym do upamiętnienia początków ich dyscypliny. Jest to równocześnie okrągła rocznica odzyskania przez Polskę niepodległości po ponad stu latach niewoli, powodowanej kolejnymi rozbiorami dokonywanymi przez ówczesne ościenne mocarstwa ${ }^{1}$. Związek obu wydarzeń mógłby być niezauważalny. Jednakże, z uwagi na ujawniane intencje twórczyni polskiej pedagogiki społecznej oraz działania społeczne i naukowe podejmowane w ciągu pierwszej dekady lat 1908-1918, można przyjąć, że rozwój polskiej pedagogiki społecznej był jednym ze swoistych zwiastunów wolności, o którą walczyła

${ }^{1}$ N. Davies, Boże igrzysko. Historia Polski, przekł. E. Tabakowska, Kraków 1992, s. 113-210; H. Orsza (Radlińska), Dzieje społeczne Polski, Warszawa 1921. 
piórem i czynem Helena Radlińska². W walce tej nie była odosobniona czy też osamotniona. Współuczestniczyła w społecznym ruchu działaczy, którzy współpracując na wszystkich możliwych polach aktywności społecznej, politycznej, gospodarczej, oświatowej, kulturalnej, a przede wszystkim wychowawczej - tworzyli fundamenty pod odradzającą się Polskę ${ }^{3}$.

Społeczny romantyzm, który wydobywał „najlepsze wartości” z przeciwstawianych sobie idei romantyzmu i pozytywizmu ${ }^{4}$, stanowił impuls dla działalności narodowo-wyzwoleńczej pokolenia Polaków urodzonych w niewoli, a marzących o wolności i niepodległości ojczyzny. Klimat społeczny tamtych lat oddała Helena Radlińska opisując wydarzenia z młodości, w których wspominała swe zaangażowanie $\mathrm{w}$ krzewienie kultury narodowej, rozbudzanie aspiracji wolnościowych i świadomości konstytuującej tożsamość Polaków żyjących $\mathrm{w}$ reżimach prawnych oraz instytucjonalnych narzuconych przez zaborców ${ }^{5}$.

Zamierzeniem niniejszego artykułu jest powrót do treści wystąpienia Heleny Radlińskiej, która 25 kwietnia 1908 roku uczestniczyła w obradach Krakowskiego Koła Towarzystwa Nauczycieli Szkół Wyższych. Wygłoszony tam odczyt uznaje się za punkt progowy nowej nauki, jaka narodziła się w zniewolonej jeszcze Polsce - pedagogiki społecznej. Wynikające z referatu przesłanie społeczno-oświatowe pozostaje w silnym związku z ideałem wolności. Autorka we wcześniejszych swych publikacjach wyrażała tęsknotę za niepodległością Rzeczypospolitej. Potwierdzała tym samym związek tworzonej nauki z potrzebą praktyki społecznej, która będzie służyła przetwarzaniu warunków społecznych, instytucjonalnych, a także politycznych. Celem była wolność i niepodległość Polski. Jednoznacznym dowodem spójności słowa i czynu był akt wstąpienia Heleny Radlińskiej w szeregi Legionów Polskich Józefa Piłsudskiego. Mimo zachęty do pracy naukowej, jakie czynił jej wówczas (1914 rok) prof. Stanisław Krzyżanowski, seminarzystka po raz pierwszy sprzeciwiła się drogiemu jej profesorowi i czasowo porzuciła pracę naukową, by czynnie włączyć się w walkę o suwerenną Polskę . Kiedy wczesną jesienią 1915 roku przedostała się konspiracyjnie do Warszawy ${ }^{7}$, jednoznacznie

${ }^{2}$ J. Strumińska (H. Radlińska), Posiew wolności: listy Joasi Strumińskiej z etapów i zestania, Zakład Graficzny „Nasza Księgarnia”, Warszawa 1935.

${ }^{3}$ Helena Radlińska przy licznych okazjach wspominała swych współdziałaczy zaangażowanych w sprawy społeczne i narodowo-wyzwoleńcze. Patrz: H. Radlińska, Nasz udział w budowaniu nowego życia, Warszawa 1937; H. Radlińska, Z dziejów pracy społecznej i oświatowej, Wrocław 1964, s. 359 i n.

${ }^{4}$ H. Radlińska, Z dziejów pracy społecznej i oświatowej, s. 334.

5 Tamże, s. 331 i n.

${ }^{6}$ Tamże, s. 358.

${ }^{7}$ Konspiracyjny charakter przeprawy do Warszawy wiązał się z nielegalnym pobytem Heleny Radlińskiej na terenie zaboru ruskiego. Jako uciekinierka z „zesłania” była narażona na 
zdeklarowała intencje swej służby narodowo-wyzwoleńczej. Aktywność tę przedkładała ponad sprawy nauki i oświaty. Oddaje to sytuacja spotkania z warszawskimi działaczami oświatowymi, którą autorka opisała po latach w materiale autobiograficznym:

Po dostaniu się do Warszawy w sposób nie pozbawiony ryzyka usłyszałam od jednej z najbardziej oddanych pracownic oświatowych A. Czerwińskiej: „przyjechaliście zapewne w sprawach uniwersytetów powszechnych, jak to dobrze". Odpowiedziałam, że bardzo mi bliskie są sprawy UL, lecz głowę nadstawia się nie za nie, lecz za to, co pozwoli je zakładać i spokojnie prowadzićs

Cytat ten oddaje perspektywę, która wyznaczała kierunek zaangażowania Heleny Radlińskiej w latach 1914-1918. Najważniejsze było odzyskanie niepodległości i stworzenie wolnego państwa, w którym możliwy będzie rozwój wszelkich form instytucjonalnych i organizacyjnych służących odbudowie Państwa Polskiego po latach niewoli i rozbiorów. Aktywność naukowa była wtórna wobec wyzwań chwili, na którą generacja autorki czekała od lat najmłodszych ${ }^{9}$. Pragnienia te oddaje cytat pieśni przywołanej przez Helenę Radlińską we wspomnieniach opisujących pierwsze lata niepodległości: Wolnej my Polsce stużym jużं10.

Można postawić pytania o zasadność powrotu do tekstów sprzed ponad wieku, o ich aktualność i tym podobne. Szczególnie w dobie intensywnych zmian cywilizacyjnych, którym towarzyszy zintensyfikowana promocja konformizmu czy nawet hedonizmu, warto odnieść się do tak formułowanych pytań. Poza jubileuszowym charakterem tego powrotu, okazją jest również możliwość skorzystania z wolności, jaka towarzyszy opracowaniu przedmiotowego wspomnienia ${ }^{11}$. Publikacje Heleny Radlińskiej, które powstawały

aresztowanie i karne konsekwencje związane ze statusem zbiega politycznego. Mimo to odważyła się przekroczyć granicę i realizować zadania operacyjne Legionów Polskich.

${ }^{8}$ H. Radlińska, Z dziejów pracy społecznej i oświatowej, s. 372.

9 Tamże, s. 367.

10 Tamże, s. 373.

${ }^{11}$ Można z nadzieją zakładać, że tekst ten nie będzie przedmiotem cenzury pseudonaukowej, co nierzadko ma miejsce w środowisku nauki (nie tylko polskiej). Zdarza się bowiem, że pod pozorem recenzji, reprezentanci środowiska naukowego wykorzystują swój przywilej swoistej władzy. Dla zablokowania druku "cenzurowanego" tekstu, z którym nie zgadzają się ideologicznie, wyrażają oni takie oczekiwania względem autorów, które w praktyce oznaczają konieczność radykalnej zmiany treści tekstu bądź rezygnację z jego publikacji. Można oczywiście szukać kolejnych Wydawców i tak niejednokrotnie dzieje się. Jednakże zjawisko narzucania autorom własnych preferencji teoretycznych, metodologicznych, a niekiedy nawet ideologicznych jest jednoznacznie niekorzystne. Trudno tego typu sytuacje określać inaczej jak patologia. Praktyki tego typu warto podnosić $\mathrm{w}$ dyskursie środowiskowym i merytorycznie ujawniać ich szkodliwy wpływ na kierunki rozwoju naukowego odpowiednich dziedzin, dyscyplin, czy subdyscyplin. Warto również troszczyć się o środowisko naukowe, by z działalności recenzyjnej eliminować czyny i postawy cenzorskie. Upowszechnianie się tego typu praktyk utrudnia pro- 
w okresie PRL-u oraz w latach wcześniejszych zostały częściowo opracowane w czterech tomach dzieł zebranych. Pośmiertnie opatrzono je nazwiskiem Heleny Radlińskiej i wydano w latach 1961-1979'2. Ich edycji towarzyszyły jednak działania cenzorskie, typowe dla okresu, w którym zbiory zostały oddane $\mathrm{w}$ ręce Czytelników ${ }^{13}$. Przedmiotowy tekst nie został ujęty w żadnym z wydanych tomów. Stąd zdaje się, że warto przybliżyć jego treść, aby tą drogą upowszechnić fakty towarzyszące początkom dyscyplinaryzacji polskiej pedagogiki społecznej i zainspirować do samodzielnego studium tekstu, który jest uznawany za pierwsze dzieło stanowiące kanon źródeł społecznopedagogicznych w naszym kraju. Tym samym, odrzuca się w tym rozważaniu intencję tak zwanej współczesnej reinterpretacji tekstu czy porównawczą analizę jego recepcji. Tego typu podejście do analizy historycznych tekstów źródłowych nie wpisuje się w przyjętą tu drogę poznania i prezentacji dokonań autorskich fundatorki polskiej pedagogiki społecznej. Celem jest zaś przybliżenie treści referatu z 1908 roku i uwrażliwienie na zagadnienia pedagogiki społecznej stawiane przez Helenę Radlińską u progu dyscyplinaryzacji tej nauki. Służyć temu będą liczne odwołania do tekstów autorskich prof. Heleny Radlińskiej oraz cytaty, które stanowią wyraz faktograficznej perspektywy przyjętej $\mathrm{w}$ tym projekcie naukowym. Jest to tym samym sposób na przekazanie głosu samej Autorce w brzmieniu oryginalnym ${ }^{14}$. Twór-

ces rozwoju naukowego, obniża jakość naukowej twórczości i osłabia morale reprezentantów środowiska akademickiego. Uwaga ta nie dotyczy sytuacji, w których recenzent (kierując się wyłącznie względami merytorycznymi) zwraca uwagę na błędy rzeczowe lub wskazuje (podpowiada) drogę doskonalenia techniki pracy naukowej, co jednoznacznie służy podnoszeniu jakości dzieła dopuszczonego do druku.

${ }_{12}$ H. Radlińska, Pedagogika społeczna, Wrocław 1961; taże, Zagadnienia bibliotekarstwa i czytelnictwa, Wrocław 1961; taże, Z dziejów pracy społecznej i oświatowej; taże, Oświata i kultura wsi polskiej, Warszawa 1979.

${ }_{13}$ Realia i warunki, w jakich do druku w oficjalnym obiegu (akceptowanym przez czynniki polityczne władz PRL) dopuszczano prace naukowe, artystyczne, a także teksty dziennikarskie, mogą być współcześnie enigmatyczne, szczególnie dla grupy młodych Czytelników. Warto tym bardziej przypominać te mechanizmy, które krępowały wolność słowa i swobodę wyrażania poglądów. Chodzi tu w szczególności o przypomnienie prawdy historycznej, jak i zapobieganie występowaniu podobnych mechanizmów w przyszłości. Historia zatacza koła, a historyczna świadomość może chronić ludzkość przed powrotami do praktyk skutkujących destrukcją, a niekiedy nawet tragedią cywilizacyjną. Na reglamentacji wolności słowa opierały się systemy totalitarne (komunizm, faszyzm). Warto o tym pamiętać również przy okazji rozważań o prawdzie i wolności w nauce.

${ }^{14}$ Doświadczenia wydawnicze skłaniają do kolejnej uwagi czynionej na marginesie rozważań. Dotyczy ona cytatów, które według niektórych zwolenników podejść interpretatywnych nie powinny mieć miejsca, lub co najwyżej "mogą” odnosić się do „kilkuznakowych” fragmentów. Zarówno w prawie, jak i zwyczajach naukowych nie obowiązują ograniczenia dotyczące długości cytowanych fragmentów dzieł źródłowych. Można wręcz przyjąć, że dużo bardziej naukowym działaniem będzie oddanie głosu w danej kwestii cytowanemu autorowi, niźli wypaczanie jego poglądów w toku błędnej interpretacji lub celowego wyrywania $\mathrm{z}$ kontekstu frag- 
czość Heleny Radlińskiej wciąż zdaje się marginalizowana w środowisku naukowym. Potwierdzeniem tego mogą być podejmowane w latach 2013-2016 w Katedrze Pedagogiki Społecznej Uniwersytetu Łódzkiego próby zgłoszenia projektów badawczych orientowanych na zgromadzenie, uporządkowanie i upowszechnienie dostępu (wydanie w wersji cyfrowej oraz drukowanej) do spuścizny prof. Heleny Radlińskiej. Propozycje tego typu działań badawczo-edytorskich nie zyskały uznania wśród ekspertów krajowych instytucji redystrybuujących środki finansowe na realizację badań naukowych ${ }^{15}$. Pozostaje strategia ponawiania prób aplikacyjnych oraz małe formy wyrazu, w których głos będzie oddany Helenie Radlińskiej ${ }^{16}$.

\section{Z zagadnień pedagogiki społecznej - Kraków, 25.04.1908 rok}

Zabierając głos w obradach Krakowskiego Koła Towarzystwa Nauczycieli Szkół Wyższych, Helena Radlińska przedstawiła wywód poświęcony

mentów twórczości, które mają rzekomo uzasadniać „forsowane” tezy. Analizując liczne prace naukowe, nierzadko spotykałem się z krótkimi cytatami wyrywanymi z kontekstu szerszej wypowiedzi. Zabiegi tego typu były niejednokrotnie próbą legitymizacji zgłaszanych poglądów, jakoby spójnych z wypowiedziami innych uznanych autorytetów naukowych. W przypadku odwoływania się do stanowisk osób nieżyjących, nie daje się cytowanemu autorowi możliwości rewizji tego typu nadużyć, szczególnie, gdy są one sprzeczne z treścią i wymową dzieł zmarłego autora. Stąd przyjęta tu koncepcja licznych i stosunkowo długich cytatów, które w zamierzeniu zbliżą Czytelnika do źródeł przywoływanego tekstu. Zabieg ten, w przypadku odwołań do myśli Heleny Radlińskiej, jest szczególnie uzasadniony. Dostęp do jej prac jest wciąż ograniczony, a teksty opracowane i wydawane po 1945 roku były poddane mechanizmom cenzury politycznej okresu PRL.

${ }^{15}$ Dane dotyczące projektów badawczych, które były zgłoszone przez pracowników Katedry Pedagogiki Społecznej UŁ w ramach "Narodowego Programu Rozwoju Humanistyki” (2013) oraz programu „Pomniki polskiej myśli filozoficznej, teologicznej i społecznej XX i XXI wieku" (2016) są dostępne w sprawozdawczości Wydziału Nauk o Wychowaniu Uniwersytetu Łódzkiego.

${ }^{16}$ Dla rozwiania wątpliwości prawnych warto dodać, że cytaty dzieł autorów, którzy nie nałożyli na utwory naukowe klauzul ograniczających, są jednoznacznie dozwolone. Zgłaszane niekiedy $\mathrm{w}$ środowisku ograniczenia $\mathrm{w}$ tym zakresie nie znajdują uzasadnienia zarówno prawnego, jak i merytorycznego. W przypadku przywoływania dzieł Heleny Radlińskiej istnieje szczególne uzasadnienie oddania głosu samej Autorce, gdyż jej dzieła w znacznej mierze są rozproszone, a dostęp do wielu z nich wymaga prowadzenia badań archiwalnych. Takie badanie było przeprowadzone na przełomie listopada i grudnia 2017 roku w zasobach Biblioteki Uniwersytetu Łódzkiego, gdzie zgromadzona jest spuścizna Heleny Radlińskiej. Zachował się także egzemplarz maszynopisu tekstu z 1908 roku, który był upowszechniony na łamach czasopisma Muzeum, rocznik XXIV, tom II, zeszyt 2, rok 1908, Lwów, s. 52-63. W niniejszym tekście odwołuję się do maszynopisu znalezionego wśród zbiorów przekazanych po śmierci prof. Heleny Radlińskiej do BU€ przez prof. Irenę Lepalczyk - uczennicę i współpracowniczkę prof. H. Radlińskiej. 
zagadnieniom pedagogiki społecznej sytuowanej w szerokim kontekście uwarunkowań społecznych i oświatowo-wychowawczych. W szczególności odniosła się do kwestii powszechności wychowania, rozwoju społecznego oraz reform szkolnych (oświatowych) na przestrzeni wieków. Wystąpienie można podzielić na trzy zasadnicze części: 1) ogólne wprowadzenie czynione z perspektywy makro, 2) rozważania szczegółowe dotyczące kwestii szkolnych na terenach ziem polskich pod zaborami ruskim, pruskim i austriackim oraz 3) pedagogiki społecznej, która jest naukową postulatorką upowszechnienia (uspołecznienia) wychowania i rozwoju społecznego.

W pierwszej części prelegentka zarysowała ogólne tło przeobrażeń w szkolnictwie światowym oraz krajowym. Towarzyszyła temu perspektywa holistyczna, z której wyłaniał się integracjonizm ujmowania spraw szkolnych ściśle powiązanych ze sprawami społecznymi - społecznego rozwoju. W szczególności Helena Radlińska zaprezentowała dwa ścierające się poglądy na naturę zmian i rozwoju ludzkiego. Stwierdzała w toku swego wywodu, że zasadzie "przetwórzmy duszę człowieka" przeciwstawia się zasadę „zmieńmy warunki tamujące rozwój człowieka, a dusze ludzkie wyszlachetnieją" ${ }^{\prime 7}$. Na marginesie można dodać, że spór między tak zwanymi "zwolennikami genetyzmu" i „deterministami społeczno-środowiskowymi” jest wciąż aktualny. W konkluzji tego wprowadzenia autorka stwierdziła, że obydwie zasady dopełniają się, a ich wzajemna relacja uwidacznia się najwyraźniej w kontekście wychowania młodzieży, które warunkuje zarówno teraźniejszość, jak i przyszłość.

Wyłaniające się z treści referatu indywidualizm, kooperatywizm, konstruktywizm oraz personalizm uwidaczniają podejście autorki do analizowanych zagadnień. Ma ono swe źródło w pedagogicznym ujęciu zjawisk i procesów społecznych stanowiących obszar zainteresowania społeczno-pedagogicznego. Centralnym podmiotem jest tu człowiek (jako indywiduum) i grupy ludzkie (jako rodziny, społeczności itp.), zaś wychowanie stanowi kluczową kategorię wyznaczającą optykę postrzegania stanów, zjawisk i procesów będących przedmiotem poznania i działalności pedagogicznej (społeczno-pedagogicznej). Związek spraw społecznych i wychowawczych zarysowała Helena Radlińska w historycznym przeglądzie zmian zachodzących w szkolnictwie. Odtworzyła tym samym dzieje pedagogiki w skali światowej i krajowej. Podkreślając związki wychowania z przeobrażeniami w nauce i kulturze, wskazała, że najważniejszą rolę w doraźnym wymiarze pełnią działacze społeczni i nauczyciele z jednej strony, z drugiej zaś politycy. Dla pierwszej grupy wychowanie jest sposobem na realizację misji społecznego

${ }_{17}$ Radlińska, 1908, s. 1. Ten i kolejne cytaty tekstu Heleny Radlińskiej z 1908 roku odnoszą się do maszynopisu zachowanego w zasobach Biblioteki Uniwersytetu Łódzkiego - spuścizna Heleny Radlińskiej (zasoby przed opracowaniem archiwalnym - brak stosownej sygnatury). 
rozwoju i tworzenia warunków dla podnoszenia kultury życia codziennego jednostek i grup społecznych. Druga zaś grupa jest zainteresowana zmianami w szkolnictwie dla wzmacniania swej pozycji i utrwalania struktur, w których mogą sprawować władzę i kontrolę. Uwaga sprzed ponad wieku zdaje się wciąż aktualna, choć formy dyskursu oraz wzajemne przenikanie się przedstawicieli środowisk pedagogicznych, społecznych i politycznych sprawia, że granice tracą swą wyrazistość.

Helena Radlińska w swym wystąpieniu jednoznacznie opowiadała się za bezwarunkowym upowszechnieniem i rozszerzaniem szkolnictwa. Prezentując mentalne i formalne bariery, z jakimi spotykały się idee ogólnego nauczania, referentka przywoływała poglądy Komeńskiego, Basedowa, Rousseau, Pestalozziego, czy Helvetiusa. Odwołując się na tym tle do tradycji polskiej, mówiła ona, że:

W Polsce, w której żyją silniej niż gdzie indziej podówczas poglądy demokratyczne/w ograniczonym kole szlachty/, już w wieku XVI słychać pragnienie, aby szkoły były „seminarium Rzplitej”. W epoce reform - szkoła ma służyć odrodzeniu ojczyzny ${ }^{18}$.

Przytaczając dorobek Komisji Edukacji Narodowej oraz poglądy na wychowanie i szkolnictwo o. Stanisława Konarskiego, autorka ukazała efekty, które sytuowały polską szkołę na przełomie XVIII i XIX wieku w gronie najbardziej obywatelskich i postępowych. Jej istota zasadzała się na symbiozie nauki i życia oraz potrzeb ludzkich. Przywołując założenia programowe, Helena Radlińska przypomniała zarazem, że Komisja edukacyjna włączyła w obszar działalności wychowawczej dwa zasadnicze cele, które gwarantują szczęśliwość szczególną - człowieka oraz szczęśliwość publiczną. W sferze ludzkiej wymieniono:

zdrowie, cnotę, obyczaje, rozsądek pewny, dobry rząd domowy, miłość, przyjaźń oraz szacunek u drugich. W zakresie szczęśliwości publicznej wskazywano równą i najściślejszą sprawiedliwość, prawodawstwo mądre, obronę krajową, cnoty obywatelskie, niepodległość w zdaniu, szlachetność myśli i postępków, szanowanie jako najświętsze własności cudzej ${ }^{19}$.

Zasadniczą misją działalności wychowawczej było przygotowanie młodego pokolenia Polaków do przeprowadzenia reform i rozwoju ojczyzny. Jak podkreślała prelegentka, podstawowym celem szkoły było wychowanie wolnego, pełnego człowieka i urzeczywistnienie ideału wolnego życia. Jednakże, tak formułowane hasła, założenia i cele nie wytrzymały zderzenia z przemocą absolutyzmu, który szkołę traktował jako narzędzie kontroli ży-

${ }^{18}$ H. Radlińska, Z zagadnień pedagogiki społecznej (maszynopis), 1908, s. 2-3.

19 Tamże, s. 4. 
cia społecznego. Eksponując sytuację polskiego szkolnictwa w poszczególnych zaborach, Helena Radlińska wykazała antagonizm dwu zasad. Pierwsza, głosząca ideę szkolnictwa uspołecznionego, hołdowała idei uzdalniania jednostek do warunków życia obywatelskiego opartego na samodzielności sądów (myśli i poglądów). Druga, narzucana przez zaborców, forsowała koncepcję wytwarzania rzeszy poddanych oraz użytecznych dla monarchy urzędników ${ }^{20}$.

Charakterystyka szkolnictwa na ziemiach polskich w okresie rozbiorów uwidoczniła jednoznacznie zależność wychowania od decyzji politycznych i strukturalnych. Na przykładzie redukcji treści programowych oraz modelu organizacyjnego "szkoły pod zaborami”, prelegentka wykazała wsteczny charakter wdrażanych zmian. Ich celowość egzemplifikowała obrazem z zaboru ruskiego, wskazując w prost na związek spraw oświatowych i społecznych:

Społeczeństwo polskie w zaborze rosyjskim gnębione na wszystkich polach życia, osłabiane co chwila wyrywaniem dzielniejszych jednostek, wstrząsane zwątpieniem, przytłoczone ogromem krzywd, bez protestu znosiło duszenie wszystkich objawów życia narodowego. Nie tylko znosiło, lecz przepłacało szkołę apuchtinowską, błagało o przyjęcie do niej swych dzieci, bo ta szkoła i jedynie ona dawała - patent, przywilej, który uwalniał od paroletnich katuszy z karabinem u nogi gdzieś w śnieżnej dali, bo ona jedynie uprawniała do dalszego kształcenia się, które dawało chleb. Społeczeństwo godziło się nawet na utrzymywanie prywatnych szkół z "prawami” - dawało dobrowolnie swoją krwawicę na nowe placówki rusyfikacyjne - za ten kawałek papieru ${ }^{21}$.

20 Tamże, s. 5.

${ }^{21}$ Tamże. Fragment ten jednoznacznie uwidacznia trudną przeszłość polskiego narodu w relacjach z zaborcą rosyjskim. Zważywszy, że tekst ten jest uznawany za pierwszy publiczny wyraz naukowej tożsamości pedagogiki społecznej, zdaje się, że winien być włączony w zakres tomu dzieł zebranych i tytułowanych "Pedagogika społeczna” (Ossolineum, Wrocław, 1961). Został on jednak pominięty w toku prac redakcyjnych/wydawniczych. Zasadne zdaje się podjęcie badań historycznych, które umożliwią wyjaśnienie tej i podobnych spraw związanych z marginalizacją (a niekiedy wykluczeniem) w okresie PRL-u określonych fragmentów twórczości naukowej. Spuścizna Heleny Radlińskiej obejmuje liczne prace publikowane w okresie poprzedzającym II wojnę światową. Były one marginalizowane po 1944 roku w projektach wydawniczych objętych cenzurą służb PRL. Obecnie wnioski projektowe w tym zakresie są regularnie składane do odpowiednich instytucji, ale równie regularnie są odrzucane. Można na marginesie ubolewać, że recenzenci, chowający się za kurtyną „ukrytej recenzji”, nie dostrzegają wartości w łączeniu pracy naukowej ze służbą ojczyźnie. Być może przykład działalności patriotycznej wpisującej się w służbę naukową Heleny Radlińskiej jest dla niektórych współczesnych „ekspertów” swoistym lustrem. Odbicie to może budzić kompleksy i prowadzić na ścieżkę cenzury uprawianej tym razem w obszarze działalności „naukowej”. Postulowana przez Helenę Radlińską jawność życia publicznego skłania do podejmowania działań na rzecz jawności recenzji projektów naukowych zgłaszanych do instytucji pośredniczących. Zdaje się, że konstruktywne byłoby zastąpienie zasady ukrytej recenzji zasadą odpowiedzialności recenzenta za rzetelność i naukową poprawność przywoływanych w recenzji argumentów. Sprawa ta dotyczy nie tylko projektów związanych z badaniami o charakterze historycznym. 
W konkluzji tej części wywodu autorka stwierdziła, że sprawa szkolna jest ściśle związana z ustrojem państwa i układem społecznym. Kontrastując modele państwa absolutystycznego i biurokratycznego z demokracją Rzeczypospolitej, Helena Radlińska podkreśliła, że dziecko jest w polskim modelu traktowane jako przyszły obywatel, zdolny do wytwarzania dóbr wspólnych. Nie jest to przyszły poddany, ani podwładny, ale współtwórca dzieł służących jednostce i ogółowi (społeczeństwu). Na tym tle przekonywała, że rolą szkoły jest tworzenie warsztatu dla przyszłości i pomyślności (szczęśliwości) ludzkiej. Wskazując doświadczenia systemowe (szkolne) z USA, Anglii, Australii, a także Szwajcarii i krajów skandynawskich, eksponowała walory decentralizacji szkolnictwa. Uwolnienie szkół od władz centralnych ułatwia dostosowanie szkoły do lokalnych potrzeb życia. Rozwiązania wychowawcze stają się w ten sposób przystające do warunków aktualnych i nadążają za zmianami zachodzącymi w codzienności. Podkreślała przy tym, że nauczyciel nie jest i nie może być urzędnikiem zależnym od polityków. Wyrażała to wprost:

Nauczyciel nie jest urzędnikiem, zależnym od ludzi nic z ideałami pedagogicznymi nie mających wspólnego, lecz kierownikiem młodzieży, gdzieniegdzie wybieranym przez gminę. Jest obywatelem, powołanym do udziału w pracy publicznej, podczas gdy państwo biurokratyczne czyni go niewolnikiem murów szkolnych ${ }^{22}$.

Przypominając stanowisko o. Grzegorza Piramowicza, podkreślała deontologiczny i aksjologiczny wymiar pełnienia służby nauczycielskiej. Szacunek wobec osoby nauczyciela przeplata się z jego postawą otwartości na pożądanie i czynienie dobra edukacyjnego, które służy ojczyźnie. $W$ podstawowy zakres działalności powszechnie szanowanego nauczyciela wpisuje się służba wychowawcza, która daje ojczyźnie jej synów²3.

Konkluzją części ogólnej i zarazem wprowadzającej tego referatu było stwierdzenie, w którym Helena Radlińska oddała społeczno-pedagogiczną perspektywę rozpatrywania wszelkich zagadnień znajdujących się w obszarze poznania dyscyplinarnego. $W$ okresie późniejszym reguła tu wyrażona znajdowała swe zastosowanie w pracy akademickiej i treściach wykładów prelegentki. Ta metodologiczna zasada brzmiała następująco:

Na każde zagadnienie patrzeć należy nie tylko z bliska, w szczegóły i szczególiki jego wglądając, ale lecz i z oddalenia - z tego oddalenia, które daje rozpatrywanie jakiejś sprawy w związku z całokształtem zagadnień życiowych - tylko wówczas ocenić można drogi do upragnionego celu wiodące ${ }^{24}$.

\footnotetext{
${ }^{22}$ H. Radlińska, Z zagadnień pedagogiki społecznej, s. 7.

${ }^{23}$ Tamże, s. 8.

${ }^{24}$ Tamże.
} 
Prezentując słuchaczom Krakowskiego Koła Nauczycieli Szkół Wyższych ogólną część wprowadzającą do referatu, autorka podkreśliła, że dopełnienie wywodu wymaga przeniesienia analizy na poziom poszczególnych zagadnień szczegółowych. Otworzyła tym samym drugą część swego wystąpienia, w której umieściła kwestie szkolnictwa narodowego na ziemiach polskich pod zaborami. Problematykę "polskiej” szkoły rozpatrywała na tle ówczesnych warunków politycznych, administracyjnych i społecznych. Przywołując stanowiska S. Szczepanowskiego, W. Lutosławskiego i J. Benoni-Dobrowolskiej, referentka wyjaśniała, że o polskości czy narodowym charakterze szkoły nie decyduje wyłącznie język wykładu i administracji bądź narodowość uczniów oraz ich nauczycieli. Desygnaty te nie wystarczą, zdaniem Heleny Radlińskiej, do ukonstytuowania polskiej szkoły narodowej. Konieczne jest przywrócenie duchowego wymiaru dumy narodowej, którą naród polski utracił w ciągu minionych lat zaborów. Okres ten sprzyjał niszczeniu dóbr narodowych - „świętości naszych" ${ }^{25}$. Dumne poczucie narodowości wśród jednostek tworzących naród polski było więc kolejnym komponentem koniecznym do wypełnienia murów szkolnych wewnętrzną siłą polskości. Przywołując to zagadnienie w XXI wieku, należy pamiętać, że naród polski był wówczas podzielony przez zaborców na trzy odrębne części. W każdym zaborze Polacy byli nękani szykanami ekonomicznymi, administracyjnymi i propagandowymi (rusyfikacja i germanizacja). Sytuacja ta osłabiała morale narodowe Polaków i skutkowała podatnością na populistyczne hasła stosowane $\mathrm{w}$ polityce prowadzonej przez zaborców na ziemiach polskich. Stąd w wystąpieniu Heleny Radlińskiej tak silna krytyka szkoły, której nazwa i język stwarzały pozór polskości, ale nie przekładało się to na proces wychowania dzieci i młodzieży do polskości. Nie nawiązywano w tej szkole do tradycji wywodzonej z polskich doświadczeń okresu Komisji Edukacji Narodowej. Nie kształtowano postaw obywatelskich odpowiadających ideałowi wolności, samodzielności myślenia i działania w imię ideału dobra wspólnego - dobra narodowego. Stąd przywoływane stanowiska hołdujące idei wychowania historycznego (zarówno w ujęciu elitarnym, jak i egalitarnym) konfrontowała Helena Radlińska z własnym poglądem na naturę polskiej szkoły narodowej. Nawiązując do naturalistycznej koncepcji J.J. Rousseau oraz ustawodawstwa Sejmu 4-letniego, pokazywała ona polską szkołę, w której dzieci będą poznawały zarówno przeszłość, jak i teraźniejszość własnego kraju, jego bogactwa, tradycje, prawa i potrzeby. W ten sposób autorka łączyła przeszłość z teraźniejszością i przyszłością. Odnosząc się do aktualnej wówczas sytuacji szkoły polskiej stwierdzała, że szkolnictwo średnie przygotowuje „urzędników z patentem" przy równoczesnej indolencji w zakresie kształcenia pra-

\footnotetext{
${ }^{25}$ Tamże, s. 9.
} 
cowników samodzielnych, zdolnych do twórczej służby. Wyraziła to wprost w twierdzeniu: „Pomiędzy szkołą a życiem nie ma związku” ${ }^{26}$. Jest to kolejny fragment sprzed ponad stu lat, który można uznać za wciąż aktualny mimo upływu lat i zmiany sytuacji geopolitycznej Polski.

Zjawisko „patentyzacji”, występujące w polskiej szkole okresu rozbiorowego, piętnowała autorka przywołując te desygnaty szkoły, które powinny stanowić jej fundament ${ }^{27}$. Wskazywała tu przede wszystkim funkcję wychowawczą i twórczą. Szkoła ma być jednostką pobudzającą siły wytwórcze i duchowe narodu polskiego. Ma odpowiadać na aktualne potrzeby życia. W zamian jest ona krępowana instrukcjami, przepisami i całą otoczką administracyjną, czyniącą ze szkoły urząd patentowy ${ }^{28}$. Zestawiając zjawisko „hyperproducji inteligencji” (nadmiar ludzi wykształconych) z diagnozowanym przez badaczy zjawisk społecznych zupełnym brakiem „inteligencji”, prelegentka starała się wyeksponować instrumentalny wymiar wykształcenia w szkole podporządkowanej zaborcy. Taka szkoła nie tyle kształci i wychowuje, co przygotowuje zastępy urzędników zdolnych do realizacji celów wyznaczanych przez władze polityczne. I tu widać wyraźnie aktualność podnoszonych problemów. W konkluzji tej części rozważań Helena Radlińska stwierdziła, że:

Szkoła narodowa stanie się wówczas, gdy na każdym polu nauczania i wychowania zostanie przystosowana do potrzeb życia. Różnorodne są one, nieuświadomione dostatecznie, jedyną drogą ku ich zaspokojeniu jest nadanie szkolnictwu jak największej swobody, decentralizacja szkolnictwa, zarówno co do jego administracji jak i szczegółowych planów, przyznanie stanowiska decydującego nauczycielstwu i kołom społecznym ${ }^{29}$.

Wynikające stąd postulaty można traktować jako propozycje programowe dla reformatorów szkolnictwa polskiego i zarazem narodowego.

Analiza szkolnictwa narodowego pod zaborami stanowiła jedno z dwu głównych zagadnień podniesionych w szczegółowej części referatu. Obok

26 Tamże, s. 13.

27 Analizując cytowany fragment poświęcony polskiej szkole okresu zaborowego, można dostrzec kolejną analogię ze współczesną szkołą (wyższą). Patentyzacja przypomina dzisiejszą parametryzację obecną w życiu akademickim. Owa parametryzacja instytucjonalna przekłada się na wymiar naukowy poprzez parametryzację pracowników nauki, których zadaniem jest gromadzenie odpowiednich punktów. Jakość i naukowy walor twórczości, współdziałanie w imię dobra wspólnego zastępuje się ideą konkurencyjności oraz „wyścigiem szczurów”. Ulegają temu coraz liczniejsze zastępy reprezentantów środowiska akademickiego. Analogia ta może być kolejnym argumentem zachęcającym do analizy zagadnień poruszanych w przeszłości przez wybitnych naukowców. Lektura tekstów źródłowych może stanowić inspirację dla poszukiwania aktualnych rozwiązań prawnych, organizacyjnych, czy instytucjonalnych.

28 Por.: H. Radlińska, Z zagadnień pedagogiki społecznej, s. 12-14.

29 Tamże, s. 13. 
tego Helena Radlińska podjęła kwestię osiągnięć nauki, które jej zdaniem warunkują rozwój szkolnictwa. Ta wzajemna relacja, według prelegentki, była kluczowa dla rozważań o reformowaniu systemu szkolnego na ziemiach polskich. Nawiązując do przeszłości, wskazywała, że w okresie scholastycyzmu i za czasów Odrodzenia szkoła i nauka rozwijały się względnie harmonijnie. W szkole na bieżąco prezentowano odkrycia naukowe. Odnosząc to do sytuacji, w której analiza była prowadzona, Helena Radlińska stwierdzała, że szkoła nie nadąża z aktualizacją programów nauczania. Wyniki poznania naukowego znacząco wyprzedzają treści programowe wykładów i lekcji adresowanych do uczniów, a niekiedy również studentów.

Nauka i co do swych zdobyczy i co do metod badania idzie tak szybko naprzód, ogarnia tak rozległe dziedziny, że w "przedmioty”, paragrafy i czytanki ująć jej nie podobna. "Nauka” szkolna z wiedzą rzeczywistą nie ma nic wspólnego w gimnazjum, nieraz i w uniwersytecie. Równocześnie przygniata młodzież przeciążenie materiałem wiadomości, dat, faktów ${ }^{30}$.

Eksponując problem relacji zachodzących między osiągnięciami nauki a programami szkolnymi, autorka wyjaśniała, że na tym tle podejmowanie jakichkolwiek reform staje się wyzwaniem niemal niemożliwym. Sposobem na sukces jest, według Heleny Radlińskiej, kompleksowa i całościowa reforma programowa, która będzie obejmowała zarówno treści przedmiotów, jak i metody nauczania. Holizm dotyczy nie tylko ogarnięcia wszystkich elementów szkolnictwa, ale również ich wzajemnych powiązań, które stanowią punkt wyjścia dla nowego modelu opartego na systemowym, spójnym i całościowym podejściu do nowych rozwiązań. Receptą na programowe odciążenie uczniów jest, zdaniem autorki, redukcjonizm obejmujący tak zwane przeżytki. Konieczne jest zatem nowe dostosowanie szkoły do potrzeb życia i zdobyczy naukowych. Odwołując się do najlepszych wzorów szkolnictwa Europy Zachodniej i Ameryki, prelegentka przeciwstawiała szkole adaptacyjnej koncepcję szkoły emancypacyjnej. Podkreślała, że nie chodzi o wtłaczanie uczniom określonych porcji wiedzy, ale o ich przygotowanie do pracy samodzielnej, rozbudzania spostrzegawczości, duchowego i fizycznego wyćwiczenia, do uczestnictwa w świecie kultury. Tylko taka reforma pedagogiczna, zdaniem referentki, prowadzi do konstytuowania się szkoły narodowej ${ }^{31}$.

Przechodząc do trzeciej i zarazem zamykającej części wystąpienia, prelegentka podniosła ponownie problem zaniku funkcji wychowawczej, która najwidoczniej uwypukla się w gimnazjach. Na tym tle wyraziła najogólniejszy postulat pedagogiki społecznej - uspołecznienie wychowania ${ }^{32}$. Podkreślając

\footnotetext{
30 Tamże, s. 14.

31 Tamże, s. 14-15.

32 Por. tamże, s. 15.
} 
potrzebę upowszechnienia nauczania i wprowadzenia obowiązku szkolnego (nawet kosztem tradycyjnie pojmowanych praw naturalnych rodziców), Helena Radlińska starała się przybliżyć zagadnienie rozwoju pokoleniowego dzieci i młodzieży. Łącząc kwestie bytowe z zapotrzebowaniem rodziców na wsparcie pracownicze (otrzymywane od dzieci w prowadzeniu gospodarstwa domowego), autorka eksponowała czynnik materialny jako główne źródło warunkujące ówczesne ścieżki rozwoju dzieci i młodzieży. Stwierdzała wprost, że sytuacja reglamentacji dostępu do szkolnictwa sprawia, iż nie tyle najzdolniejsi, co najzamożniejsi uczestniczą w średnim i wyższym szczeblu edukacji. Na marginesie tego spostrzeżenia, autorka przypomniała ofiary, jakie ponosiła najuboższa młodzież polska w staraniach o awans społeczny:

Wobec dzisiejszego układu stosunków kształcą się wyżej nie jednostki najzdolniejsze, lecz najzamożniejsze - ci co z warstw tzw. niższych przez szkoły się przebijają, ponoszą ciężkie ofiary, nie tylko materialne, lecz i - bardzo często - moralne, okupują wznoszenie się na wyższy szczebel społeczny, związany dziś ze zdobyciem patentu, mnóstwem upokorzeń i trudności, a które zaprawiają goryczą dusze ${ }^{33}$.

Pokazując trudności i komplikacje występujące w procesie rozwijania potencjału sił ludzkich dzieci i młodzieży, Helena Radlińska poszukiwała rozwiązań praktycznych dla dostrzeganych ograniczeń. Można stwierdzić przy tej okazji, że zastosowana tu zasada analizowania rzeczywistości była w kolejnych latach wiodącym drogowskazem torującym drogę nowej dyscyplinie naukowej. Praktyczny jej charakter podkreślała prof. H. Radlińska w toku prezentacji punktu widzenia polskiej pedagogiki społecznej ${ }^{34}$. W kontekście trudności, jakie przewidywała referentka w związku z planami urzeczywistniania ideału uspołeczniania (upowszechniania) wychowania, wskazała konkretne instrumenty, które mogłyby stanowić kompensację dla materialnych i mentalnych ograniczeń społecznych. Zaliczyła tu różnego typu formy wsparcia dzieci i młodzieży w postaci stypendiów, burs, sponsorowanych posiłków i bezpłatnych książek dla uczniów oraz studentów z ubogich rodzin. Odwołując się do demokratycznych wzorców ustrojowych, przywoływała systemowe rozwiązania oparte na pomocy społecznej, które w innych krajach (rozwiniętych cywilizacyjnie, choć niedemokratycznych) mają swe trwałe fundamenty w rozwiniętej filantropii. Jak podkreślała w swym wystąpieniu wygłoszonym w 1908 roku, rozwiązania takie świadczą o rozwoju społecznym.

Formułując zarys programowy wsparcia dzieci i młodzieży w rozwijaniu ich potencjału sił dla dobra wspólnego, Helena Radlińska postawiła kluczowe

${ }^{33}$ Tamże, s. 16.

${ }^{34}$ Szerzej patrz: H. Radlińska, Stosunek wychowawcy do środowiska społecznego. Szkice z pedagogiki społecznej, Warszawa 1935, s. 15 i n.; taże, Pedagogika społeczna, s. 361 i n. 
pytanie o kierunki rozwoju w dziedzinie wychowania. Wpisując to zagadnienie w obszar tworzącej się w Polsce pedagogiki społecznej twierdziła, że:

W pedagogice społecznej spotykamy często marzenia o tym, jak organizacja szkolnictwa, która metodom wychowawczym da moc i rozmach, doprowadzi do zniweczenia nędzy i choroby, zapewni szczęśliwość na ziemi. Idealne obrazy przyszłości opierają się na sposobie wychowania młodzieży ${ }^{35}$.

Przywołany cytat obrazuje perspektywę, z jakiej autorka spoglądała na wychowanie i jego miejsce w polskiej pedagogice społecznej. Ideał i zapatrzenie w przyszłość było równoważone diagnozą aktualnych potrzeb i poszukiwaniem metod działalności służącej urzeczywistnianiu owego ideału. Dała temu wyraz w obronie utopii, która była wówczas silnie krytykowana przez środowiska zapatrzone $\mathrm{w}$ racjonalny pozytywizm. Łączenie zagadnień szkolnych z całokształtem życia społecznego wymaga, według Heleny Radlińskiej, spojrzenia na rzeczywistość w całości spraw i związków zachodzących między poszczególnymi elementami złożonej rzeczywistości. Bez odniesienia do całości zjawisk i procesów nie będzie możliwa kompleksowa zmiana. Jednak takie podejście nie oznacza, że szczegółowe prace muszą zakończyć się niepowodzeniem. Wizja przyszłości oparta na tym co dziś jest niemożliwe popycha do działania. Potęguje siły, które w codziennym, szarym życiu mogłoby ograniczać lub paraliżować twórczość. Jak obrazowo stwierdzała:

Sny złote nie przeszkadzają działaniu, tylko pracownikowi przypinają skrzydła. Poczucie rzeczywistości zamykać się nie może w obrębie dzisiejszych stosunków, wśród nich nawet są przyszłości odległej zwiastuny. Tej przyszłości dokładnie, we wszystkich rysach przewidzieć nie możemy - twórcami nam jeno być dane, nie prorokami ${ }^{36}$.

Konkludując powyższą obronę utopii, stwierdzała, że w pedagogice pełnią one rolę drogowskazów, wyznaczają kierunek i nie są bezużyteczne, jak niejednokrotnie postrzega się wszelkie przejawy idealizmu. To one pobudzały myśli i przyczyniały się do rozwoju, aktywizowały ludzkie siły do działania, które niejednokrotnie przekraczało zdefiniowane granice ludzkiej percepcji. W ostatnim zdaniu wyrażała to wprost: „Budować mogą tylko ci, co plan mają, prowadzić ci, co światło widzą"37.

Utopia, a w późniejszej twórczości Heleny Radlińskiej wielokrotnie przywoływany „ideał" stanowiły wyraz zamiłowania autorki do spraw przyszłych, kreślonych z wizją pomyślności i szczęśliwości ludzkiej. Teraźniejszość splatała się w tej twórczości z szacunkiem dla przeszłości oraz intencją

\footnotetext{
${ }^{35}$ H. Radlińska, Z zagadnień pedagogiki społecznej, s. 15-16.

36 Tamże, s. 17.

37 Tamże.
} 
służby przyszłości, która dokonuje się w codziennej pracy twórczej. Poszanowanie dokonań minionych pokoleń i praca dla przyszłości to ideały, które towarzyszyły Helenie Radlińskiej od wczesnych lat młodości ${ }^{38}$. Wpisały się też w naturalny sposób w program polskiej pedagogiki społecznej, która jako nauka praktyczna rozwijała się w późniejszych okresach pod silnym wpływem twórczyni i jej współpracowników - uczniów.

\section{W stronę przyszłości}

Przybliżenie treści wystąpienia programowego Heleny Radlińskiej, które stało się progowym punktem rozwoju polskiej pedagogiki społecznej, warto kontynuować powrotami do innych znaczących dla dyscypliny tekstów źródłowych. Spuścizna naukowa przywołanej autorki obejmuje inne dzieła, które do tej pory nie zostały upowszechnione. Są to prace z zakresu metodologii, badań prowadzonych wśród emigrantów polskich we Francji, a także wskazania metodyczne dla pracy oświatowej, społecznej i bibliotecznej. Na uwagę zasługują także teksty, które powstawały w latach 1914-1918, a dotyczyły bezpośrednio walki narodowo-wyzwoleńczej, w której Helena Radlińska czynnie uczestniczyła. Zagadnienia te wpisują się w fundamentalny zakres badań społeczno-pedagogicznych dotyczących historii pracy społecznej i oświatowej. Podsumowując niniejszy projekt wydawniczy (tzw. małą formę projektu naukowego), można zaryzykować tezę, że powrót do przeszłości jest nie tylko wartościowy historycznie. Może przede wszystkim wzmacniać dyscyplinarną pozycję nauki, której siła tkwi w jej ontologicznym statusie. Ów status decyduje o związku polskiej pedagogiki społecznej ze sprawami życia ludzkiego. W jej deontologicznym wymiarze podkreśla się z kolei użyteczność działań podejmowanych przez pedagogów społecznych w polu aktywności poznawczej, teoriotwórczej i praktycznej. Cechy te, w połączeniu z całokształtem zagadnień cywilizacyjnych XXI wieku, sytuują pedagogikę społeczną w ścisłym gronie nauk niezbędnych i koniecznych dla konstruktywnego rozwoju społecznego.

\section{BIBLIOGRAFIA}

Davies N., Boże igrzysko. Historia Polski, przekł. E. Tabakowska, Społeczny Instytut Wydawniczy "Znak", Kraków 1992.

Orsza H. (Radlińska), Dzieje społeczne Polski, Towarzystwo Wydawnicze Ignis, Warszawa 1921.

${ }^{38}$ Patrz: H. Radlińska, Z dziejów pracy społecznej i oświatowej, s. 331. 
Radlińska H., Z zagadnień pedagogiki społecznej (maszynopis), 1908.

Radlińska H., Stosunek wychowawcy do środowiska społecznego. Szkice z pedagogiki społecznej, Nasza Księgarnia, Warszawa 1935.

Radlińska H., Nasz udział w budowaniu nowego życia, Zakłady Drukarskie Wacława Piekarniaka, Warszawa 1937.

Radlińska H., Pedagogika społeczna, Ossolineum, Wrocław 1961.

Radlińska H., Zagadnienia bibliotekarstwa i czytelnictwa, Ossolineum, Wrocław 1961.

Radlińska H., Z dziejów pracy społecznej i oświatowej, Ossolineum, Wrocław 1964.

Radlińska H., Oświata i kultura wsi polskiej, Ludowa Spółdzielnia Wydawnicza, Warszawa 1979.

Strumińska J. (H. Radlińska), Posiew wolności: listy Joasi Strumińskiej z etapów i zestania, Zakład Graficzny „Nasza Księgarnia”, Warszawa 1935. 